\title{
Step off the Misunderstanding Area of "Competition"
}

\author{
Yanhua Zhang \\ School of Economics and Management \\ Shenyang Ligong University \\ Shenyang, China \\ E-mail: zhangyh66@163.com
}

\begin{abstract}
The article is aimed at discussing China's colleges and universities of the personnel system reform, from the aspects such as the nature of competition, the characteristics of modern management, the nature of human resources management and colleges and universities' morality, is to prove that the universities carry out full internal competition for posts is wrong, and suggest to use the system to restrain or encourage the acts of university teachers rather than competition.
\end{abstract}

Keywords: Competition, Modern management, Condition of competition

In 2000, the College Department of the Communist Party of China Central Committee and the Ministry of Personnel, the Ministry of Education issued a notice on the "implement of deepening the reform of the personnel system of colleges and universities", which pointed out that introducing competitive and incentive mechanism in colleges and universities definitely. And the implementation of this advice has been widely implemented in nationwide colleges and universities.

I think that in market economy, competition is, of course, an indispensable way, but it also has its conditions and regulars. It's wrong to over-emphasis on competition when the internal talents in colleges and universities use it, without respecting the law of competition and considering the conditions, costs and other factors. Carrying out competition in colleges and universities, it reflects the low-level management, although it's good for the managers and simplifies the management work.

First, introducing competition mechanism in the internal of colleges and universities is going against the objective of competition law.

1. Contrary to one of the necessary conditions - "scope of the competition must be large enough"

The classical theory of free competition thinks: In order to the operation of competition, a certain number of buyers and sellers is essential, and the more the number of the two parties, the more intense competition. Colleges and universities take the needs of the development of each discipline into account which needs to maintain a reasonable structure of the teacher, with the result the competition can not be carried out extensively within the frame work of the whole school, but only in the disciplines and even professional conducts, The number of teachers in each of the professional is limited, because of the restrictions of the scale of the school and the number of students. When introducing competition within colleges and universities, people from all departments become competitors, it also undermine the unity between the teachers and the department's internal relationships change very complex. As a result, introduction of competition mechanisms in the internal of colleges and universities is clearly contrary to the necessary condition that the scope of the competition must be large enough.

\section{Contrary to the condition that "In order to start to play its role, competition must be in the basically fair environment"}

In this regard, we can be verified form fair theory and competitive model.

Fair theory thinks that, the staff of the Organization have tendency to revalue their own work and gain reward. They not only concern about their own remuneration's absolute value, but also concern about the relative value of their remuneration. Everyone, consciously or unconsciously, may compare the labor they paid and the reward they gained with others, they also compare their own labor income and reward in the past with that of now. When they find their own balance of payments and the proportion of other people's balance of payments equal to the ratio, or an equal of the proportion of their current revenue and expenditure and that of the past, they will have a sense of fairness and strengthen the power of work; otherwise, they would feel unfair, and affect their work enthusiasm. The formula of the content of the fair theory can be expressed as following: 
Comparing formula: A reward / input; B reward / input (A represents for their own; B is on behalf of another person) The comparing results:

$\mathrm{A}=\mathrm{B}$, rewards are well-balanced, feel impartial;

$\mathrm{A}>\mathrm{B}$, rewards are more than inputs or gains more than others, the reward is too high, have a sense of guilty;

$\mathrm{A}<\mathrm{B}$, rewards are less than inputs or gains less than others, fell suffering losses, wrongly ,and indignant.

From the fair theory: the fairness of distribution depends on the sense of subjective judgments and feelings of interested party, and psychological factors play a decisive role. The standard of the fairness of the distribution is often subjective, and varies from person to person, depending on the major party's personality, needs, motivations, values and other factors. At present, the main method of work that colleges and universities reforms is: the teachers' professional ethic, teaching and academic achievements are the basis of appraising teacher post. The academic achievements is the most important and decisive in the three evaluation factors. We do not discuss such an evaluation method is whether or not scientific, in China's environment where academic corruption is very serious, the number and the level of academic achievements is difficult to reflect the academic standards of teachers truly. It determines that in colleges and universities the implementation of fair competition is difficult to do, and unfair competition will inevitably dampen the enthusiasm of teachers.

Competition model assumes that the two persons to compete for the two organizational posts for the boss and staff. Through the establishment of mathematical models and a series of derivation conclud that: the promotion not only depends on the of people's efforts, also depends on the luck factor. If luck occupies a dominant position in the outcome of the decision-making promotion, then the employees will not be promoted to work at it.

These two theories imply: to achieve the purpose of the competition, on the one hand, we need to create a relatively fair environment, on the other hand to maximizely eliminate the influences that the luck factor put on the outcome of competition. In fact, in the implementation of internal competition in our colleges and universities, it is difficult to do that, without a scientific evaluation criteria to evaluate the teachers' academic level and a just academic, scientific research environment, in which case, is bound to lead to unfair competition, which will dampen the enthusiasm of the teachers.

\section{Competing in the internal Colleges and universities will have many negative effects}

The implementation of internal competition in Colleges and universities, would create a large number of negative effects. Mainly: (1) to affect the unity between the teachers; (2) is not conducive to academic and professional development; (3) to frustrate the outcome of a high level academic achievements, because of competition makes academic collaboration between the high level teachers become almost impossible; (4) to enable teachers to assume a heavy psychological pressure which is not conducive to the teachers' learning, teaching and research work; (5) to encourage the academic corruption, in order to produce more results, especially produce "high level " results to achieve school's examination standards, many teachers have become very impulsive, and take a lot of improper means and methods, such as: plagiarize other people's academic results, and make other Latin American relations in order to get scientific research projects.

Second, the over-emphasis on internal competition in colleges and universities goes against the laws of modern management.

In modern society, with the arrival of knowledge economy, various knowledge and technology continue to renew, the division of labor is more detailed, institutions of higher learning within the subject is divided into smaller and teachers' research expertise is more and more narrow and detailed. A study of a topic, often involving many subjects, so it needs for more co-operation to complete. In many cases, teachers rely on the ability of individuals find it difficult to fully deal with a variety of complex information and take concrete and effective action, all of which require further interdependence, interrelated, and cooperation between the university teachers, that is to form a new team , to advocate team spirit within colleges and universities.

Advocating team spirit in colleges and universities, can make its members learn from each other and make up for the personal ability or mental limitations, and through coordinated action, to maintain the ability of colleges and universities to cope with the continuous innovation capacity, so as to avoid leading to internal discord by implementing internal competition in colleges and universities; let's work together towards a same goal, share responsibility and the joy of success; also create a caring atmosphere where the team members are interdependence, so that team members have a sense of belonging, a sense of responsibility and allowing teachers to relax with each other, work with pleasure to form a "family" situation, and show the mutual concern of the people in the same boat.

In short, in modern society, colleges and universities in the in-house should emphasis on cooperation rather than competition, and it is clearly that the introduction of competition within colleges and universities goes against the social development of people to cooperate. 
Third, the over-emphasis on internal competition in colleges and universities makes the teachers in the Prisoner's Dilemma.

Most of the books about game theory introduce such a story: when serious warehouse arson occurred, police captured two suspects $\mathrm{A}$ and $\mathrm{B}$ at the scene. It was in retaliation for the fact that they worked together and set fire to the warehouse, but police did not have enough evidence. As a result, the police imprisoned them separately, come clean with the requirements. If they were admitted arson, will each be jailed for three years; if they were not accountable because of insufficient evidence, they would each only have one year's imprisonment; if one denied and the other confessed, the one who denied would be imprisoned for five years, and the confessor would be released, free from criminal punishment. In this example we can see that only both A and B offenders alliance, not honest,will get the best results; but the police through the introduction of the condition that "a denial and the other honest and willing to testify, then that who deny will have the five-year imprisonment, and confessor would be the release of large, free from criminal punishment", together with the asymmetric information of the two criminals of A and B, so that both A and B offenders become a competitive relationship, and everyone frankly in order to pursue their own interests to the greatest, the result is that everyone had been sentenced to three years in prison, opted for severe punishment. I think the implementation of internal competition in colleges and universities, as this example, make teachers act in the pursuit of personal interest to maximize, not in order to enable colleges and universities to achieve optimal efficiency,and don't complete the purpose of management which is to improve the work efficiency.

Today the social division of labor is more and more detailed, it is necessary to improve the working efficiency of colleges and universities, on the one hand, require the establishment of an effective system and make sure that the appointment of a clear need to be completed during the various indicators, such as establishing the standards separately from the development of a teaching assistant to a professor teaching in class, as well as scientific research should meet so that all categories of personnel have a clear understanding of their objectives, and Practically to do a good job in the nature of their work, then the school's personnel department carry out strict examination, according to the results of the examination to make the title and level of employment of the next phase; on the other hand, to improve the quality of managers and management, through their effective management, to mobilize the enthusiasm of their staff, mining the potential things of employees; through bounding the system and management, to improve labor efficiency.

\section{References}

Edward Lazear. (2000). Economics of Personnel Management, Beijing: Beijing University Press.

Jie, Shujiang. (2005). China's capital market based on the theory of competitive analysis, Beijing: China Economic Publishing House, November.

Sun, Jianmin \& Zhou, Wenxia. ( 2004). Management Incentive, Beijing: Management of University Press. 